\title{
IDENTIFICATION OF THE REACTIVE SITES IN TWO HOMOLOGOUS SERINE PROTEINASE INHIBITORS ISOLATED FROM BARLEY
}

\author{
by \\ IB JONASSEN and IB SVENDSEN \\ Department of Biotechnology, Carlsberg Research Laboratory \\ and \\ Department of Chemistry, Carlsberg Laboratory \\ Gamle Carlsberg Vej 10, DK-2500 Copenhagen, Valby
}

Keywords: Hiproly barley, high lysine, chymotrypsin, subtilisin, potato inhibitor I

Chymotrypsin inhibitors CI-1 and Cl-2 from barley were subjected to limited hydrolysis by subtilisin Carlsberg, subtilisin Novo and chymotrypsin. Analysis of CI-2 derived peptides by amino acid sequencing identified peptide bond, $\mathrm{Met}^{59}-\mathrm{Glu}^{60}$, as the reactive site towards these three proteinases. In contrast, inhibitor $\mathrm{CI}-1$ showed a single reactive site $\left(\mathrm{Leu}^{59}-\mathrm{Asp}^{60}\right.$ ) towards chymotrypsin and two reactive sites $\left(\mathrm{Met}^{30} \mathrm{Ser}^{31}\right.$ and $\mathrm{Leu}^{59}-\mathrm{Asp}^{60}$ ) towards either of the subtilisins.

\section{INTRODUCTION}

The high lysine content of Hiproly barley originates mainly from its lysine-rich, water soluble albumin fraction $(4,8,11,13)$. Attempts to identify the proteins responsible for the high lysine content of the Hiproly albumin fraction led to the isolation and characterization of a lysine-rich protein of molecular weight 9,100 which was originally named SP II albumin after the chromatographic fraction from which it was obtained $(7,8)$. This protein was later demonstrated to be an inhibitor of chymotrypsin and subtilisin (17). It is therefore desirable to rename the protein, chymotrypsin inhibitor 2 (CI-2), in accordance with this activity (17).

In addition to CI-2, Hiproly endosperm contains another chymotrypsin inhibitor named CI-1 (6). It has been shown that the two barley inhibitors and an inhibitor from leach (Hirudo medicinalis) display extented amino acid sequence homology with potato inhibitor I (16) and thus they belong to the "potato inhibitor I family" (17).

Abbreviations: $\mathrm{CI}-1$ and $\mathrm{Cl}-2=$ chymotrypsin inhibitor 1 and 2 from barley, GPNA = glutaryl-1-phenylalanine-pnitroanilide, Polybrene $=$ hexadimethrine bromide, $\mathrm{PTH}=$ phenylthiohydantoin, SDS-PAGE $=$ sodium dodecyl sulfate polyacrylamide gel electrophoresis, THEED $=\mathrm{N}, \mathrm{N}, \mathrm{N}^{\prime}, \mathrm{N}^{\prime}$,-tetrakis (2-hydroxyethyl) ethylenediamine. 
It has been shown that the inhibitory action in the majority of specific serine proteinase inhibitors are localized to a specific reactive (inhibitory) peptide bond situated within a loop closed by a disulfide bridge (15). Such a loop is not, however, present in the two barley inhibitors. The purpose of the present communication is to identify the reactive sites of these inhibitors and to compare them with reactive sites found in other members of the "potato inhibitor I family".

\section{MATERIALS AND METHODS}

\subsection{Materials}

Hordeum vulgare cv. Hiproly was grown at Carlsberg Plant Breeding's farm "Hyldagergård" in the summer of 1979. Subtilisin Novo, subtilisin Carlsberg and porcine chymotrypsin were gifts from Novo Industri, Copenhagen. All reagents and solvents used with the sequencer have been described previously (18). Glutaryl-1phenylalanine-p-nitroanilide (GPNA) was from Sigma, St Louis, USA. Sephadex G 75 Superfine was from Pharmacia Fine Chemicals, Uppsala, Sweden and Biogel P-10 was a product of Calbiochem AG, Switzerland. DEAE- and CMcelluloses, types DE-52 and CM-52, were from Whatman, Maidstone, England. Unless otherwise specified, all other chemicals were of analytical grade and were used without further purification.

\subsection{Methods}

\subsubsection{Sodium dodecyl sulphate polyacrylamide} gel electrophoresis (SDS-PAGE)

The analytical slap gel electrophoretic system was a $1 \mathrm{~mm}$ thick $7.5-15 \%$ gradient of polyacrylamide using a discontinous alkaline buffer system $(3,14)$. All samples were prepared as described in (3).

\subsubsection{Chymotrypsin inhibitor assay}

Inhibitors of chymotrypsin were assayed at $37^{\circ} \mathrm{C}$ with GPNA as substrate $(2,5)$. A $0.1 \mathrm{ml}$ sample of inhibitor was preincubated for $10 \mathrm{~min}$ with $0.15 \mathrm{ml} 0.001 \mathrm{M}-\mathrm{HCl}$ containing $0.8 \mathrm{mg}$. $\mathrm{ml}^{-1}$ of chymotrypsin. $2.5 \mathrm{ml}$ substrate solution (0.4 mg GNPA $\cdot \mathrm{ml}^{-1}, 0.02 \mathrm{M}-\mathrm{CaCl}_{2}, 0.05 \mathrm{M}-$ Tris- $\mathrm{HCl}, \mathrm{pH}$ 7.6) were then added and incubation continued for another $10 \mathrm{~min}$. The reaction was stopped by addition of $1.0 \mathrm{ml} 20 \%$ acetic acid in methanol and the absorbance measured at 410 $n m$. The inhibitor content of the samples was diluted to give an inhibition in the range of 20 $70 \%$. One inhibitor unit was defined as the amount of inhibitor required to inactivate $1 \mathrm{mg}$ of chymotrypsin.

\subsubsection{Isolation of chymotrypsin inhibitor $C I-I$}

Isolation of chymotrypsin inhibitor CI-1 was achived by a modification of the method of MIKOLA and SoulinNA (12). Lyophilized watersoluble albumin prepared as described earlier (7) was dissolved in elution buffer $(0.005 \mathrm{M}-2$-mercaptoethanol, $0.010 \mathrm{M}$-Tris- $\mathrm{HCl}, \mathrm{pH} \mathrm{8.0)}$. The sample was applied to a column $(2.6 \times 21 \mathrm{~cm})$ of DEAE-cellulose equilibrated with elution buffer and subsequently eluted with a linear $\mathrm{NaCl}$ gradient $(0.0-0.12 \mathrm{M})$ in the same buffer. $14 \mathrm{ml}$ fractions were collected at a flowrate of $95 \mathrm{ml} \cdot \mathrm{h}^{-1}$. The CI-1 containing fractions were dialyzed against elution buffer $(0.005 \mathrm{M}$-2-mercaptoethanol, $0.02 \mathrm{~m}$-acetate, $\mathrm{pH} 4.5$ ). The sample was then applied to a column $(1.6 \times 8 \mathrm{~cm})$ of $\mathrm{CM}$ cellulose equilibrated with the same buffer and subsequently eluted with a gradient of $\mathrm{NaCl}$ (0.0-0.5 M). $1.7 \mathrm{ml}$ fractions were collected at a flow rate of $120 \mathrm{ml} \cdot \mathrm{h}^{-1}$. The CI-1 containing fractions were concentrated by evaporation and applied to a column $(1.6 \times 88 \mathrm{~cm})$ of Sephadex $G$ 75 pre-equilibrated with the same buffer. $2.1 \mathrm{ml}$ fractions were collected at a flowrate of $2 \mathrm{ml} \cdot \mathrm{h}^{-1}$ and the CI-1 containing fractions were dialyzed and lyophilized. The purity of the isolated inhibitor CI-1 was controlled by activity measurements (section 2.2.2.) and by SDS-PAGE (section 2.2.1.) which showed that the preparation only contained one band.

\subsubsection{Proteolytic cleavage of chymotrypsin inhibitor CI-I and CI-2}

Cleavage of inhibitor $\mathrm{CI}-1$ and $\mathrm{CI}-2$ with a catalytic amount of either chymotrypsin, subtilisin Carlsberg or subtilisin Novo were performed at low $\mathrm{pH}$ as recommended by OzawA and LAsKowski (15). The following $\mathrm{pH}$ values were chosen in the present study to give the highest yield of cleaved inhibitor. Inhibitor CI-1 and CI-2 were cleaved at $\mathrm{pH} 3.0(0.1 \mathrm{M}$-glycine- $\mathrm{HCl}$ buffer $)$ by chymotrypsin whereas $\mathrm{CI}-1$ were cleaved at $\mathrm{pH}$ 3.5 (0.1 M-ammonium acetate buffer) by subtili- 
sin Carlsberg and subtilisin Novo. Inhibitor CI-2 was likewise cleaved by subtilisin Carlsberg and subtilisin Novo at $\mathrm{pH} 4.5$ in the same buffer. The peptides produced in this way were separated by gel filtration on a Biogel P10 column $(0.9 \times 120$ $\mathrm{cm}$ ) equlibrated with $30 \%$ acetic acid. Fractions of $1 \mathrm{ml}$ were collected with a flow-rate of $1.4 \mathrm{ml}$. $\mathrm{h}^{-1}$. Peptides were located by their absorption at $280 \mathrm{~nm}$, by SDS-PAGE, and by the arginine spot test described by YAMADA and ITANo (20).

Alternative cleavage of inhibitor CI-2 by subtilisin Carlsberg and subtilisin Novo was obtained as follows. One $\mathrm{mg}$ of inhibitor and two $\mathrm{mg}$ of enzyme was dissolved in $0.7 \mathrm{ml} 0.05 \mathrm{M}$ Tris- $\mathrm{HCl}$ buffer, $\mathrm{pH} 8.0$ (17). The inhibitor-enzyme complex was isolated by gel filtration on a Sephadex G 75 column $(1.6 \times 88 \mathrm{~cm})$ equilibrated with $0.1 \mathrm{M}-\mathrm{NH}_{4} \mathrm{HCO}_{3} .2 .1 \mathrm{ml}$ fractions were collected at a flow-rate of $2 \mathrm{ml} \cdot \mathrm{h}^{-1}$. The appropriate fractions were pooled and lyophilized. The lyophilized enzyme-inhibitor complex was thereafter redissolved in $30 \%$ acetic acid. This procedure liberated a mixture of subtilisin, intact inhibitor and inhibitor cleaved at the reactive site. The peptides were separated by gel filtration as described for inhibitors cleaved at low $\mathrm{pH}$. The two elution profiles displayed the same characteristics, the profile obtained for the subtilisin Carlsberg CI-2 complex is presented in Figure 1.

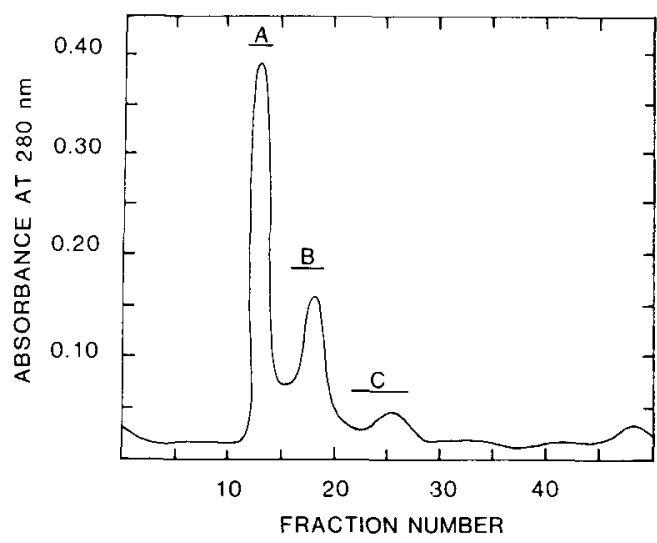

Figure 1. Separation of peptides derived from the denatured inhibitor CI-2-subtilisin Carlsberg complex on Biogel P10 in 30\% acetic acid.

Bars indicate the identified peptides. A. Subtilisin Carlsberg. B: Peptides derived from CI-2 with N-terminals starting at: Asn ${ }^{11}, \mathrm{Gly}^{13}$ and $\mathrm{Ala}^{14}$. C: peptides derived from $\mathrm{CI}-2$ with $\mathrm{N}$-terminals starting at Glu ${ }^{60}$.

\subsubsection{Amino acid sequence determinations}

For the determination of the amino acid sequences, an automatic liquid phase sequencer, Beckmann, model $890 \mathrm{C}$ was used with programme 122974 supplied by this firm. However, $0.1 \mathrm{M}$ $\mathbf{N}, \mathbf{N}, \mathbf{N}^{\prime}, \mathbf{N}$ ',-tektrakis(2-hydroxyethyl)-etylendiamine (THEED) was used instead of $1.0 \mathrm{M}$-Quadrol, and ethylacetate contained 15\% propanol as recommended by BEGG and MORGAN (1). In all cases hexadimetrine (Polybrene) was added to the cup as described by TARR et al. (19). Identification of PTH-amino acids was done by high pressure liquid chromatography and thin layer chromatography as described earlier (18).

\section{RESULTS AND DISCUSSION}

Inhibitor CI-2 forms a very stable complex with either of the subtilisins near neutral $\mathrm{pH}$ (17). Due to the very tight binding of CI-2 to the subtilisins it was anticipated that some of the inhibitor present in the complex was cleaved at the susceptible bond of the reactive site. Advantage was taken of the fact that the subtilisins denature quickly at low $\mathrm{pH}$, and that suspending the subtilisin-inhibitor complex in solution at acid $\mathrm{pH}$ liberates the inhibitor as a mixture of intact inhibitor and inhibitor cleaved at the reactive site. Amino acid sequencing of the peptides isolated by gel filtration of the denatured complexes between CI-2 and subtilisin Carlsberg or subtilisin Novo, respectively, showed that inhibitor CI-2 in part had been cleaved at peptide bond Met $^{59}-G^{60}$ (Figure 2). These results are in agreement with the effects of serine proteinases on their inhibitors as described by LASKOWSKI and KATO (10) although neither CI-1 nor CI-2 is stabilized by disulfide bridges. In this respect they are unique among the proteinase inhibitors isolated from higher plants (17).

OzaWA and LaskowsKI (15) have showed that partial hydrolysis of a specific reactive (inhibitory) peptide bond in trypsin inhibitors could be obtained by incubation of the inhibitors at low $\mathrm{pH}$ with a catalytic amount of their cognate proteinase. Amino acid sequence analysis of peptides obtained by incubation of $\mathrm{CI}-2$ at low $\mathrm{pH}$ with catalytic amounts of either chymotrypsin, subtilisin Carlsberg or subtilisin Novo respectively identified the reactive site of $\mathrm{CI}-2$ as peptide bond $\mathrm{Met}^{59}-\mathrm{Glu}^{60}$. The reactive site identified in 


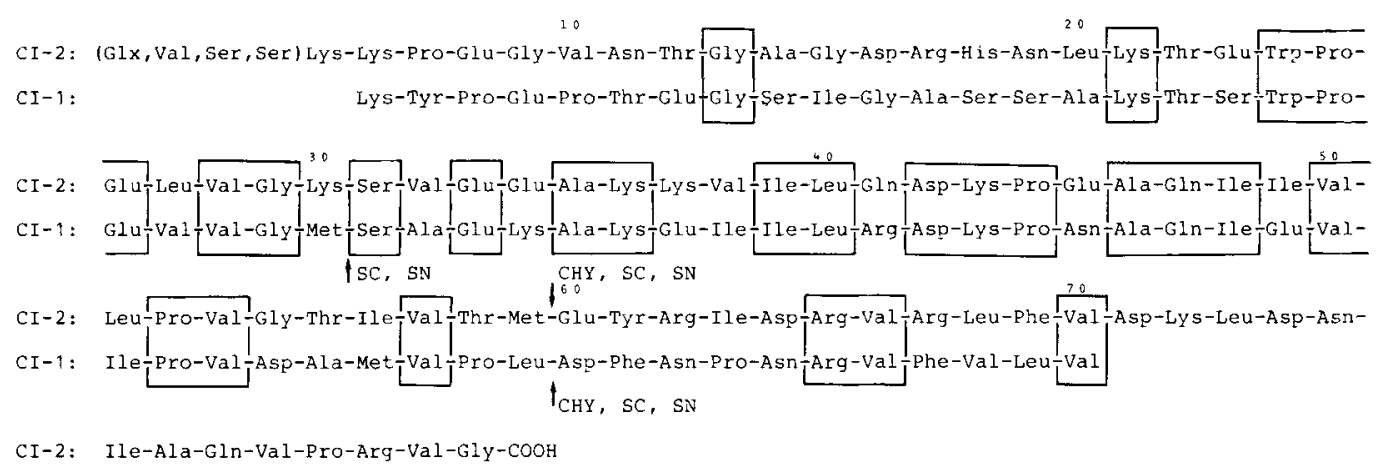

Figure 2. Primary structure of barley chymotrypsin inhibitor CI-1 and CI-2.

Active sites towards the three proteinases are indicated by arrows. Abbreviations: $\mathrm{CHY}=$ chymotrypsin, $\mathrm{SC}=$ subtilisin Carlsberg; $\mathrm{SN}=$ subtilisin Novo.

this way is identical to the reactive site obtained from the denatured complex between $\mathrm{CI}-2$ and either subtilisin Carlsberg or subtilisin Novo as described above.

When CI-1 was subjected to cleavage at low $\mathrm{pH}$ by catalytic amounts of either of the three proteinases, two cleavage sites were obtained. The two subtilisins cleaved CI- 1 at peptide bonds Met $^{30}-\mathrm{Ser}^{31}$ and Leu ${ }^{59}-$ Asp $^{60}$ with approximately the same efficiency but chymotrypsin cleaved CI1 only at peptide bond Leu ${ }^{59}-$ Asp $^{60}$. In addition a minor, presumably non-specific, cleavage site was obtained at $\mathrm{Glu}^{33}-\mathrm{Lys}^{34}$ by subtilisin Novo. From the amino acid sequence homologies between the two barley inhibitors (CI-1 and CI-2), leech inhibitor and potato inhibitor $\mathrm{I}$ it was inferred that the reactive site of inhibitor $\mathrm{CI}-1$ and $\mathrm{CI}$ 2 were localized to peptide bond $\mathrm{Leu}^{59}-\mathrm{Asp}^{60}$ and $\mathrm{Met}^{59}-\mathrm{Glu}^{60}$, respectively (16). However, the second reactive site of $\mathrm{CI}-1\left(\mathrm{Met}^{30}-\mathrm{Ser}^{31}\right)$ was quite unexpected from the amino acid sequence homo$\operatorname{logy}$ in this region compared to that of CI-2 and the other members of the potato inhibitor I "family". Mikola and Soulina (12) studied the activity of inhibitor CI-1 towards chymotrypsin and microbial serine proteinases. Their study indicated that the inhibitor CI-1 forms a 1:1 complex with chymotrypsin and a 2:1 complex with subtilisin. These data are in good agreement with the cleavage sites obtained in the present study suggesting that CI-1 is "single-headed" towards chymotrypsin (Leu ${ }^{59}-$ Asp $^{60}$ ) but "double-headed" towards either of the subtilisins (Met ${ }^{30}-\mathrm{Ser}^{31}$ and Leu $^{59}$-Asp ${ }^{60}$ ).

Inhibitor CI-1 was formerly isolated and se- quenced with a "ragged" $\mathrm{N}$-terminus starting at $\mathrm{Tyr}^{7}$ or $\mathrm{Glu}^{9}$ (16) using the numbering of the present study (Figure 2). However, the prominent $\mathrm{N}$-terminal residue in the present study was Lys $^{6}$ together with small amounts of longer sequences, as seen from the occurence of the single Tyr in positions later than expected. Unfortunately, the sequence data were too mixed to enable a clear determinination of the $\mathrm{N}$-terminal sequence, but the data indicate the presence of nine more residues. In the present study residues No. 19 and 60 were determined to be Ser and Asp instead of Gly and Asn residues as previously found (16).

The different $\mathrm{N}$-terminals observed in the present study were also found in the case of inhibitor CI-2 which was originally isolated together with three smaller, immunologically identical peptides (7). Amino acid sequencing and in vitro protein synthesis demonstrated that the small peptides were produced by proteolytic cleavage of inhibitor CI-2 $(9,18)$, and that the release of 11 to 17 amino acid residues from the $\mathrm{N}$-terminal did not affect the inhibitor activity of CI-2 (17). This finding is also in agreement with the observation that when inhibitor CI-2 with a blocked N-terminal residue was used to form the complex with the subtilisins, the resulting $\mathrm{N}$-terminal peptide always displayed the known "ragged" form. It is probable that during complex formation excess subtilisin has cleaved various peptide bonds in the $\mathrm{N}$-terminal sequence of the inhibitor. The presence of several Pro and Gly residues in this part of the molecule suggest a "random coil" structure which would make attack by proteolytic enzymes 
easier. Such a mixture of a proteolytically degraded inhibitor gives a distinct chromatographic pattern (2) which should not be interpreted as isoinhibitor patterns $(7,9,18)$. CI-1 was sequenced with a "ragged" $\mathrm{N}$-terminus (16) which might have been produced by endogenous proteinases during purification. This conclusion is supported by the fact that a different isolation procedure used in the present study suggested the presence of additional 10 amino acids.

\section{ACKNOWLEDGEMENTS}

The skilled technical assistance of BoDIL CoRNELIUSSEN and LONE SøRENSEN is gratefully acknowledged. JoHN MUNDY is thanked for his help in correcting the language. We also thank professor MARTIn OtTESEn for a critical review of the manuscript.

\section{REFERENCES}

1. BEGG, G. \& F. J. MoRGan: A non-volatile buffer with improved performance in automated protein sequencing. Febs. Lett. 66, 243-245 (1976)

2. Boisen, S., C. Y. Andersen \& J. HejgaArd: Inhibitors of chymotrypsin and microbial serine proteases in barley grains. Isolation, partial characterization and immunochemical relationships of multiple molecular forms. Physiol. Plant. 52, 167-176(1981)

3. Chua, N. -H. \& P. Bennoun: Thylakoid membrane polypeptides of Chlamydomonas reinhartii: Wild type and mutant strains deficient in photosystem II reaction center. Proc. Nat. Acad. Sci. US 72, 2175-2179 (1975)

4. El-Negoumy, A. M., C. W. Newmann \& B. R. Moss: Chromatographic fractionation and composition of the components of the salt-soluble proteins from Hiproly (CI 3947) and Hiproly normal (CI 4362) barleys. Cereal Chem. 54, 333-334 (1977)

5. Erlanger, B. F., F. Edel \& A. G. Cooper. The action of chymotrypsin on two new chromogenic substrates. Arch. Biochem. Biophys. 115, 206-210 (1966)

6. Hejgaard, J. \& S. Boisen: High-lysine proteins in Hiproly barley breeding: Identification, nutritional significance and new screening methods. Hereditas 93, 311-320 (1980)

7. JoNASSEN, I.: Characteristics of Hiproly barley
I. Isolation and characterisation of two watersoluble high-lysine proteins. Carlsberg Res. Commun. 45, 47-58 (1980)

8. JONASSEN, I.: Characteristics of Hiproly barley II. Quantification of two proteins contributing to its high lysine content. Carlsberg Res. Commun. 45, 59-68 (1980)

9. Jonassen, I., J. Ingversen \& A. Brandt: Synthesis of SP II albumin, $\beta$-amylase and chymotrypsin inhibitor $\mathrm{CI}-1$ on polysomes from the endoplasmic reticulum of barley endosperm. Carlsberg. Res. Commun. 46, 175-181 (1981)

10. Laskowski, M. JR., \& I. Kato: Protein inhibitors of proteinases. Ann. Rev. Biochem. 49, 593-626 (1980)

11. Miflin, B. J. \& P. R. Shewry: The synthesis of proteins in normal and high lysine barley seeds. In: Recent advances in the biochemistry of cereals. D. L. Laidman \& R. G. Wyn Jones, eds., Academic Press London, 239-273 (1979)

12. Mikola, J. \& E. -M. Soulinna.: Purification and properties of an inhibitor of microbial alkaline proteinases from barley. Arch. Biochem. Biophys. 144, 566-575 (1971)

13. MUNCK, L.: Improvement of nutritional value in cereals. Hereditas 72, 1-128 (1972)

14. Neville, D. M. JR.: Molecular weight determinations of protein dodecyl sulfate complexes by gel electrophoresis in a discontinuous buffer system. J. Biol. Chem. 246, 6328-6334 (1971)

15. Ozawa, K. \& M. JR. LaskowsKI: The reactive site of trypsin inhibitors. J. Biol. Chem. 241, 3955-3961 (1966)

16. Svendsen, I., S. Boisen \& J. Hejgaard: Amino acid sequence of serine proteinase inhibitor CI-1 from barley. Homology with barley inhibitor CI-2, potato inhibitor I, and leech eglin. Carlsberg Res. Commun. 47, 45-53 (1982)

17. Svendosen, I., I. Jonassen, J. Hejgaard \& S. BoIsen: Amino acid sequence homology between a serine protease inhibitor from barley and potato inhibitor I. Carlsberg Res. Commun. 45, 389-395 (1980)

18. Svendsen, I., B. Martin \& I. Jonassen: Characteristics of Hiproly barley III. Amino acid sequences of two lysine-rich proteins. Carlsberg Res. Commun. 45, 79-85 (1980)

19. TARr, G., J. F. Beecher, M. Bell \& D. J. MCKean: Polyquarternary amines prevent peptide loss from sequenators. Anal. Biochem: $84,622-627(1978)$

20. Yamada, S. \& H. A. Itano: Phenanthrenequinone as an analytical reagent for arginine and other substituted guanidines. Biophys. Biochim. Acta 130, 538-541 (1966) 